This essay is part of IJARBM's special issue

"Contemporary Applied Business Research

in Light of Standard Academic Literature".

\title{
Understanding Theoretical Aspects of Outsourcing: Common Features and Discrepancies Between Transaction Costs Economics and Contractual Incompleteness
}

\section{A Reflective Study Based on Prominent Authors}

\author{
Quentin Commine \\ commine@unistra.fr \\ Université de Strasbourg, Strasbourg, France \\ https://doi.org/10.51137/ijarbm.2022.3.1.1
}

\begin{abstract}
Outsourcing is a phenomenon regularly explored through two theories: transaction cost economics and incomplete contract theory. The second approach is frequently seen as an extension of the first but is it right to do so? Could the theory of incomplete contracts be regarded as a "2.0" transaction cost economics? This article addresses this question through the main theoretical axes of renowned researchers, notably by being awarded a Nobel Prize. While transaction costs, particularly theorized by Coase and Williamson, focus on an organizational perspective centered on governance, contractual incompleteness focuses on non-human assets and the mechanical aspects of contracts. We confront these two theories to show the points and counterpoints that can be overlapping but also deeply diverging. This article therefore provides a succinct point of view that allows the reader to quickly gain a perspective on the study of two theories at the foundation of the study of an ancient and pervasive phenomenon.
\end{abstract}

\footnotetext{
Keywords - Outsourcing, Transaction Costs Economics. Incom-
} plete Contracts, Governance

\section{Introduction}

Should a productive organization make or buy to maximize its income? This very long-standing question has still not lost its relevance in management science. Many theoretical frameworks have been developed to address this issue. Among them, two approaches are particularly relevant to the "mechanics" of contracts: transaction cost economics (TCE) and incomplete contract theory (ICT). Already studied in previous research (Commine, 2020), the connection between these two ideas has yet to be explored in depth to delimit the notions of transaction costs and contractual incompleteness, which can be seen considered as both distinct and related. 
Thus, sometimes confused, sometimes opposed, these two fields of study show a very particular link between them which we propose to investigate here by means of the most authoritative works currently available. In this essay, we therefore answer the following research question: How does incomplete contract theory extend transaction cost theory to the study of outsourcing?

To do so, we first present the theoretical framework through the leading authors of the two theories before comparing them to determine, in the last part of this article, the contingencies and antagonisms of both TCE and ICT.

\section{Defining Transaction Costs Economics (TCE) Through the Contributions of Coase and Williamson}

As introduced by Coase $(1937,1960)$ in the theory of the firm, this type of costs is related to the transaction process. Popularized by Stigler (1966), the Coase's theorem is a fundamental work in transaction costs economics. This principle is mainly based on the efficiency of processes (targeting the lowest possible costs) and on the invariance of resources, and materializes the costs induced by the coordination between agents (search for the offer, negotiation, contractualization, and the implementation of the contract: control, etc). Coase's contribution, which is fundamental in many fields, including institutional economics (deeply influenced by the contributions of North), demonstrates that transaction costs between agents are a rootcause of state interventionism: indeed, if the market had no transaction costs, then state intervention would not be required.

The results of Ronald Coase's initial work (Nobel Prize in 1991) are widely used in many fields including the economic analysis of law and will be extended within the framework of the theory of transaction costs economics built on the research of another Nobel Prize winner (2009): Oliver Williamson.

Williamson (e.g., 1967, 1975, 1993, 1998, 2008) also builds his definition of TCE on the concept of the bounded rationality of agents, a concept cherished by Herbert Simon (1947), winner of the Nobel Prize in Economics in 1978. Between a strict organizational hierarchy and market liberty, Williamson makes the notion of transaction costs actionable through two major types of organization. These can be either hierarchical (total integration of all the functions of the organization) or hybrid, as an intermediate form between a hierarchical entity and a complete reliance on the market.

The predominantly actionable feature of Williamson's work is found mainly in the study of the phenomenon of outsourcing. While this long-standing phenomenon has also been studied through other equally popular theoretical approaches (such as Prahalad and Hamel's Core Competencies), TCE continues to be at the center of much thinking. Through its three cardinal aspects (asset specificity, frequency of transactions, and uncertainty), TCE induces the notation of contractual incompleteness.

The action of agents to reduce this incompleteness is thus at the origin of many costs, which can be defined as transaction costs. So, is the theory 
relating to this notion of incompleteness (namely the theory of incomplete contracts) a continuation of the TCE, or can it be opposed to it?

To answer this question, which is largely related to the research question of this essay, we explore the notion of contractual incompleteness in the following section.

\section{Defining Contractual Incompleteness Through the Framework of Grossman and Hart's Research}

The incomplete contract theory provides another perspective, while at the same time complementing or even - in certain respects - extending the TCE (Hart et al., 1990). This approach refers to the informational incompleteness of the client and its supplier and is based on the major challenge for the client to monitor the performance of its supplier due to the lack of ownership rights of the assets. Hart et al (1999) state that knowing the completeness of the data in a complex contract would be prohibitively expensive for the agents: contracts are incomplete to observe the costs of fulfilling them. In the context of an incomplete contract, Grossman and Hart define the agents in charge of increasing the overall level of information in terms of residual control or decision right (Hart et al., 2007; Grossman et al. 1986). Contract renegotiation is also a central issue in contractual incompleteness. Hart et al (1988) demonstrate the importance of renegotiation mechanisms based on the reliable verifiability of messages between the parties.

We now turn to the question concerning the link between transaction cost theory and contractual incompleteness. Hart (1989) identifies a first connection between TCE and contractual incompleteness, as stated: "People often by-pass the legal process presumably because of the transaction costs of using it". Incomplete contracts therefore result from an economy in the informational process of their elaboration because of the transaction costs that would result from a more exhaustive elaboration.

\section{Similarities and Differences Between the Two Theories}

The notion of incomplete contracts and transaction cost economics are thus two concepts that can be confused because they share various common characteristics: the assumption of bounded rationality on the side of agents, incomplete information, and a focus on information symmetry. However, whereas the TCE postulates asymmetric information between agents, contractual incompleteness implies information symmetry.

In a perspective that also diverges between the two theories, TCE is more interested in governance aspects, while incomplete contract theory prefers to address the assets of the contract and the actions needed to limit the effects of contractual incompleteness. While Williamson is interested in the opportunism of the actors in a contract, other authors such as Grossman 
and Hart, or Kreps (1992), are interested in the variables that cannot be fully apprehended in the understanding of contractual mechanisms.

\section{Conclusion}

The work carried out by the great names which have been mentioned in this article is far from exhaustive. We have chosen them to show to what extent the two theories can overlap and differ in their applications. The theory of incomplete contracts cannot simply be considered as a « 2.0 » TCE: these two theories are clearly distinct although they share a ramification due to their fields of study, their origins and the interdependencies existing between their postulates. Many research and application fields therefore remain to be explored and the phenomenon of outsourcing could thus be approached in a joint manner by these two theories in order to interweave an organizational and contractual study. Many other approaches can also be studied to adress outsourcing such as the core competencies (Prahalad and Hamel, 1997) or Nooteboom's (2009) cognitive theory of the firm.

\section{References}

Coase, R. H. (1937). The nature of the firm. economica, 4(16), 386-405.

Coase, R. H. (1960). The problem of social cost. In Classic papers in natural resource economics (pp. 87-137). Palgrave Macmillan, London.

Commine, Q. (2020). Définition d'une théorie de l'externalisation dans les armées : le cas de l'Aviation Légère de l'Armée de Terre (Doctoral dissertation, Université de Strasbourg).

Grossman, S. J., and Hart, O. (1986). "The Costs and Benefits of Ownership: A Theory of Vertical and Lateral Integration." Journal of Political Economy.

Hart, O., Moore, J. (1988). Incomplete contracts and renegotiation. Econometrica: Journal of the Econometric Society, 755-785.

Hart, O. (1989). Incomplete contracts. In Allocation, information and markets (pp. 163-179). Palgrave Macmillan, London. 
Hart, O., Moore J. (1990), Property Rights and the Nature of the Firm, Journal of Political Economy, 98(6).

Hart, O., Moore, J. (1999). Foundations of incomplete contracts. The Review of Economic Studies, 66(1), 115-138.

Hart, O., Moore, J. (2007). Incomplete contracts and ownership: Some new thoughts. American Economic Review, 97(2), 182-186. https://doi.org/ $\underline{10.1257 / \text { aer.97.2.182 }}$

Kreps, D. M. (1992). Static choice in the presence of unforeseen contingencies. Economic analysis of markets and games: Essays in honor of Frank Hahn, 258-81.

Nooteboom, B. (2009).. A cognitive theory of the firm: Learning, governance and dynamic capabilities. Edward Elgar Publishing. https://doi.org/10.4337/9781848447424

Prahalad, C. K., \& Hamel, G. (1997). The core competence of the corporation. In Strategische Unternehmungsplanung/Strategische Unternehmungsführung (pp. 969-987). Physica, Heidelberg.

Simon, H. A. (1947). Administrative behavior: A study of decision-making processes in administrative organization (1st ed.). New York, NY: Macmillan.

Williamson, O. E. (1967). Hierarchical control and optimum firm size. Journal of political economy, 75(2), 123-138. https://doi.org/10.1086/259258

Williamson, O. E. (1975). Markets and hierarchies: analysis and antitrust implications: a study in the economics of internal organization. University of Illinois at Urbana-Champaign's Academy for Entrepreneurial Leadership Historical Research Reference in Entrepreneurship. 
Williamson, O., Winter, S. (1993). The nature of the firm: origins, evolution, and development. Oxford University Press.

Williamson, O. E. (1998). The institutions of governance. The American Economic Review, 88(2), 75-79. 